\title{
INTEGRATED MARKETING COMMUNICATION SEKOLAH TINGGI DESAIN INTERSTUDI SEBAGAI STRATEGI KELUAR DARI KRISIS
}

\author{
Isharyadi 1, Firman Kurniawan ${ }^{2}$, Irwansyah ${ }^{3}$, Poppy Ruliana 4 \\ STIKOM - Interstudi ${ }^{1}$, Ilmu Komunikasi Pascasarjana Universitas Indonesia ${ }^{2}$, Ilmu \\ Komunikasi Universitas Indonesia ${ }^{3}$, STIKOM - Interstudi ${ }^{4}$ \\ Isharyadi17@gmail.com ${ }^{1}$, firmankurniawan@yahoo.com ${ }^{2}$, ironesyah@gmail.com ${ }^{3}$, \\ poppyruliana30@gmail.com ${ }^{4}$
}

\begin{abstract}
This study aims to find out how Integrated Marketing Communication (IMC) is a strategy out of crisis? The analysis of this study focuses on how Integrated Marketing Communication becomes a strategy out of crisis, using planning-planning, organizing, activating, and monitoring methods that are carried out to determine and achieve targets According to George R. Terry (Terry, 1957). Through case studies and data collection techniques in the form of interviews, it is known that IMC can overcome and even exclude organizations from crises, besides being able to improve the image also has an impact on increasing student acceptance. The conclusion of this study shows that the existence of IMC activities carried out separately, although it does not have an impact on new student admissions, this strategy is able to make STDI out of crisis, IMC strategies can be a different approach for crisis-affected organizations, improving the image positive and increase public trust.
\end{abstract}

Keywords: Crisis; Integrated Marketing Communication

\begin{abstract}
ABSTRAK
Penelitian ini bertujuan untuk mengetahui Bagaimana Komunikasi Pemasaran Terpadu (IMC) sebagai strategi keluar dari krisis ? Analisa penelitian ini berfokus pada bagaimana IMC menjadi strategi keluar dari krisis, menggunakan metode perencanaan-perencanaan, pengorganisasian, penggiatan, dan pengawasan yang dilakukan untuk menentukan serta mencapai sasaran-sasaran Menurut George R.Terry (Terry, 1957). Melalui studi kasus dan teknik pengumpulan data berupa wawancara, diketahui bahwa IMC dapat mengatasi bahkan mengeluarkan organisasi dari krisis, selain dapat meningkatan citra juga berdampak pada meningkatnya penerimaan mahasiswa. Kesimpulan dari penelitian ini menunjukan adanya kegiatan IMC yang dilakukan secara terpisah pisah, meskipun tidak berdampak pada penerimaan mahasiswa baru dirasakan strategi ini mampu membuat STDI keluar dari krisis, strategi IMC mampu menjadi pendekatan yang berbeda bagi organisasi yang terkena krisis, memperbaiki citra positif dan meningkatkan kepercayaan masyarakat.
\end{abstract}

Kata kunci: krisis; komunikasi pemasaran terpadu 


\section{PENDAHULUAN}

Tidak ada satupun organisasi di dunia ini yang menginginkan krisis. Tetapi dalam banyak kejadian, krisis bisa datang tanpa disadari hadir secara tiba-tiba dan mengguncangkan suatu organisasi setelah munculnya pemberitaan di media "Sebanyak 243 perguruan tinggi di seluruh Indonesia dibekukan oleh Dirjen Dikti, Kemenristek \& Dikti pertanggal 29 September 2015 pk. 16.00 wib di forlap.dikti.go.id. 243 perguruan tinggi itu tersebar di seluruh Indonesia bahkan beberapa cukup memiliki nama besar di warga Kota masing masing seperti Sekolah Tinggi Desain Interstudi Propinsi D.K.I. Jakarta yang berada diurutan 192" (Toriq, 2015).

Sebagai ilustrasi, dapat diuraikan krisis yang melanda organisasi sebagai berikut : Sekolah Tinggi Desain Interstudi (STDI) Jakarta mengklarifikasi soal statusnya yang berubah jadi non-aktif. Kepala Sistem Penjaminan Mutu Internal STDI Jakarta, Imron Hasani, mengatakan, status non-aktif Interstudi sebenarnya sudah dikeluarkan sejak Januari 2015 lalu oleh Kemendikbud. Alasannya non-aktif, ucap Imron, lantaran pihaknya tak mengirim laporan aktivitas akademik selama 5 semester. "Ini termasuk pelanggaran ringan," kata Imron.

Efek dari pemberitaan tersebut membuat Mahasiswa Sekolah Tinggi Desain Interstudi (STDI) Jakarta, khawatir soal status kampusnya yang berubah jadi non-aktif. Uraian di atas menunjukan terjadinya krisis adalah keajadian yang tidak diharapkan, berdampak dramatis, kadang belum pernah terjadi sebelumnya yang mendorong organisasi kepada suatu kekacauan (chaos) dan dapat menghancurkan organisasi tersebut tanpa adanya tindakan nyata (Powell, 2005).

Menurut Michael Regester dan Judy Larkin, krisis merupakan suatu situasi yang membuat organisasi menjadi subyek pembicaraan kalangan luas, yang memiliki potensi untuk tidak disukai, mendapat perhatian dari berbagai media baik Nasional maupun Internasional dan berbagai kelompok lain seperti konsumen, pemegang saham, karyawan beserta keluarganya, politisi, serikat perdagangan, dan kelompok lingkungan hidup yang atas satu alas an tertentu meiliki ketertarikan terhadap segala kegiatan yang dilakukan oleh perusahaan (Regester \& Larkin, 1997: 131). Melihat dari konsep yang telah dipaparkan, pemahaman krisis tersebut juga dapat menentukan bahwa pemberitaan tentang status STDI yang dinon aktifkan yang serentak diberitakan oleh pihak media massa merupakan suatu krisis yang dialami oleh STDI.

Selanjutnya pemahaman lain yang dinyatakan oleh Rosady Ruslan juga dapat mendefinisikan bahwa masalah pemberitaan negative terhadap STDI tersebut merupakan suatu krisis lembaga. Menurut Rosasy Ruslan dalam situasi dan kondisi krisis komunikasi, perusahaan akan berhadapan dengan sorotan yang bernada negative dari masyarakat, ditambah lagi dengan tekanan "liputan" dari pihak pers atau wartawan yang 
menampilkan "pendapat" secara subjektif. Pada kondisi krisis Humas bertugas sebagai penasehat manajemen yang diberi wewenang untuk mengatasi krisis dan bertanggung jawab terhadap program yang dijalankan sesuai dengan keahlian yang dimiliki Humas (Ruslan, 1995:13).

Untuk mengantisipasi dampak negative yang akan terjadi, pihak perusahaan melalui Humas harus melakukan pengelolaan krisis dengan menggunakan strategi komunikasi krisis. Hal ini dilakukan agar perusahaan terhindar dari ancaman dampak negative yang bisa berpengaruh pada kinerja perusahaan dan produk jasa penerbangan dari perusahaan itu sendiri akibat tidak adanya pengelolaan informasi kurang baik yang tersebar di masyarakat.

Komunikasi krisis merupakan sebuah proses yang diungkapkan oleh suatu organisasi berkaitan dengan isu - isu di luar kendali (Smith, 2005). Sedangkan dari sudut pandang Humas, komunikasi krisis adalah pendekatan yang terstruktur dalam penanganan suatu kejadian, dengan tujuan untuk memberikan strategi komunikasi yang tepat sehingga informasi yang diberikan sampai kepada khalayak dengan cepat, meminimalisasi resiko kesalahan informasi dan membantu mengurangi kerugian (Murray,2001).

Peneliti berharap, penelitian ini nantinya dapat memberikan informasi kepada masyarakat bagaimana pihak STDI melalui IMC dapat keluar dari krisis ? sehingga menjadi referensi bagaimana perusahaan atau lembaga pendidikan merancang agar dapat digunakan sebagai acuan untuk kegiatan dalam mengelola krisis mengenai pemberitaan negative yang diberikan oleh media massa. Kemudian melalui penelitian ini, pihak STDI dapat mengembangkaan atau menambah konsep dalam srategi komunikasi krisis yang dimiliki oleh perusahaan untuk menangani pemberitaaan negative yang diberitakan oleh media massa.

\section{METODE PENELITIAN}

Penelitian diskriptif merupakan penelitian terhadap status, sikap, pendapat kelompok individu, perangkat kondisi dan prosedur suatu sistem pemikiran atau peristiwa dalam rangka membuat diskriptif menggunakan penelitian lapangan terhadap sejumlah atau gambaran secara sistematik dan analitik yang dapat digunakan untuk memecahkan masalah actual masa kini (Suprapto, 2013: 13)

Penelitian deskriptif umumnya tidak dimaksudkan untuk penjelasan (explanations), melainkan lebih kepada mengemukakan gambaran atau pemahaman (understanding) (Pawito, 2007:35).

Pendekatan ini diarahkan pada latar belakang dan individu sebagai yang holistic (utuh). Penelitian diskriptf tidak mengisolasikan strategi human relation ke dalam variable atau 
hipotesi, tetapi memandangnya sebagai bagian dari keutuhan. Wilayah-wilayah penelitian deskriptif meliputi : studi sensus populasi, survey opini public, study status task analysis studies, questioner and interview analysis, anectodal record, critical inciodent record.

Metode yang dipakai dalam penelitian ini adalah metode kualitatif. Metode kualitatif adalah suatu prosedur penelitian yang menghasilkan informasi.

Penelitian kualitatif didefinisikan sebagai penelitian yang bertujuan memperoleh gambaran yang rasional dan mendalam dengan memperoleh data ekstensif pada beberapa variable dengan pendekatan naturalistic inkuiri (Suprapto, 2013:13)

Penelitian ini menggunakan paradigma konstruktivis. Paradigma konstruktivis pada dasarnya memandang ilmu social sebagai analisis sistematis terhadap socially meaningful action melalui pengamatan langsung dan rinci terhadap obyek penelitian.

Penulis menggunakan paradigm konstruktivis karena penelitian ini bertujuan untuk menjabarkan suatu realitas social yaitu : usaha - usaha yang dilakukan oleh STDI dalam menangani pemberitaan negative di media massa.

Penelitan sebagai prosedur pemecahan masalah yang diselidiki dilakukan dengan menggambarkan keadaan atau objek penelitian (seseorang, Lembaga, masyarakat, dan lain-lain) pada saat sekarang berdasarkan fakta-fakta yang tampak atau sebagaimana adanya (Nawawi, 1998:31). Data yang dikumpulkan berupa kata-kata, gambar, dan bukan angka-angka. Selain itu, semua yang dikumpulkan berkemungkinan menjadi kunci terhadap apa yang sudah diteliti.

Dengan demikian, laporan penelitian akan berisi kutipan-kutipan data untuk memberi gambaran penyajian laporan (Moleong, 2002: 11). Penelitian menekankan catatan dengan deskripsi kalimat rinci, lengkap dan mendalam yang menggambarkan situasi sebenarnya mendukung penyajian data.

Metode pengumpulan data yang digunakan dalam penelitian ini adalah dalam penelitian ini, peneliti menggunakan wawancara mendalam untuk memperoleh data primer. Menurut Esteberg (Sugiyono, 2006:260), wawancara adalah pertemuan dua orang untuk bertukar informasi dan ide melalui tanya jawab, sehingga dapat dikonstuksikan makna dalam topic tertentu. Menurut Burhan Bungin dalam bukunya Metodologi Penelitian Kualitatif, wawancara adalah proses percakapan dengan maksud untuk mengkonstruksi mengenai orang, kejadian, kegiatan, organisasi, motivasi, perasaan dan sebaginya yang dilkaukan dua pihak yaitu pewawancara (interviewer) yang mengajukan pertanyaan dengan orang yang diwawancari (interviewee) (Bungin, 2007). Wawancara mendalam merupakan mengumpulkan data dengan cara langsung bertatap muka dengan informan, dengan maksud mendapatkan gambaran lengkap dengan informan, dengan maksud 
mendapatkan gambaran lengkap tentang topic yang diteliti (Bungin, 2007: 155). Dengan wawancara, peneliti akan mengetahui sesuatu hal yang lebih mendalam menginterprestasikan situasi dan fenomena yang terjadi, dimana hal ini tidak bias ditemukan dalam observasi (Sugiyono, 2006:261). Dalam penelitian ini peneliti mewawancarai para informan yang dianggap mampu menjawab pertanyaan penelitian.

Untuk mengumpulkan data-data dan teori dalam penelitian ini, peneliti menggunakan tinjauan literature. Tinjauan literature yang dilakukan oleh peneliti adalah memanfaatkan berbagai macam data dan teori yang dikumpulkan dari berbagai sumber berupa buku-buku, website, surat kabar, dan informasi sebagai penunjang penelitian, seperti dokumen, agenda dan catatan serta bahan-bahan tertulis lainnya sebagai dasar penelitian.

Keabsahan dalam menganalisis data yang digunakan dalam penelitian ini adalah analisis trianulasi sumber. Peneliti menguji data yang didapat dari membandingkan antara satu narasumber dengan narasumber lainnya pada hasil wawancara diperoleh, hasil yang didapatkan valid atau sesuai dengan teori yang dipaparkan dalam buku.

\section{HASIL DAN PEMBAHASAN}

Sikap Public Relation (PR) STDI dalam menanggapi krisis adalah dengan sikap aktif. Maksudnya dari sikap aktif PR adalah pada saat PR mengetahui permasalahan krisis tersebut, pada hari yang sama PR langsung mengkoordinasikan dengan Pengurus Yayasan, Dosen Senior dan hari itu juga keluar keputusannya.

Kemudian dalam tataran Lembaga, sikap STDI dalam menyikapi krisis adalah dengan mengembalikan penilaian kepada masyarakat, mahasiswa. Sikap untuk mengembalikan penilaian kepada masyarakat tidak diberikan secara begitu saja. STDI juga memberikan penjelasan dan fakta-fakta tentang krisis yan gsedang terjadi. STDI memberikan penejlasan kepada mahasiswa dengan mengikutsertakan fakta-fakta tentang suatu krisis yang terjadi. STDI menyampaikan penjelasan tentang fakta-fakta krisis tersebut secara masuk akal berdasarkan apa yang sudah dilakukan untuk memperbaiki krisis tersebut. Artinya bahwa informasi yang disampaikan tidak ada yang ditambahkan maupun dikurangi informasi sebenarnya. Hal ini dilakukan agar mahasiswa dapat menilai sendiri bahwa informasi yang diberikan masuk akal dan merupakan kebenaran.

Dalam menyikapi krisis, PR STDI menyikapinya dengan aktif. Aktif yang dimaksud adalah tanggap dan menyadari adanya krisis. Sikap aktif PR menurut pandangan praktisi PR sudahlah tepat. Menurut praktisi PR, PR harus aktif untuk mencari informasi mengenai organisasi dimana dia berada. Kemudian, sikap yang diambil perusahaan adalah dengan mengembalikan penilaian tentang STDI kepada masyarakat. Namun sikap 
mengembalikan penilaian kepada mahasiswa dan masyaakat tidak dengan cara begitu saja. STDI juga mengikutsertakan penejelasan tentang krisis tersebut bisa terjadi sesuai dengan fakta. Hal ini disampaikan oleh STDI secara masuk akal tanpa mengurangi dan menambahkan informasi yang sebenarnya.

\section{Strategi Public Relation}

Terdapat empat tahap yang Public Relation lakukan dalam strategi hubungan masyarakat yaitu : mengetahui permasalahan, perencanaan, mengambil tindakan dan komunikasi, dan evaluasi program. Empat tahap tersebut adalah mengetahui permasalahan (fact finding), perencanaan (planning and programing), mengambil tindakan dan komunikasi (action and communicating) dan evaluasi (evaluation).

Mencari akar masalah, apa yang terjadi saat ini ? tidak hanya mengetahui situasi, tetapi perlu dipastikan apakah yang menjadi puncak permasalahan, golongan public yang terlibat dan kebijakan atau aktivitas STDI yang berkaitan. Informasi ini dapat diperoleh melalui penelitian atau sumber non formal seperti hubungan pimpinan dengan dosen, STDI dengan Kopertais, Dosen dengan Mahasiswa.

\section{Mengetahui Permasalahan (Fact Finding)}

Informasi ini dapat diperoleh melalui penelitian atau sumber tidak formal seperti hubungan pemimpin masyarakat, serikat pekerja, pemimpin politik, dan analisis konten media (Mc clreath, 1993).

Tindakan PR untuk mengetahui permasalahan adalah dengan mengumpulkan semua pemberitaan yang terkait dengan pokok masalah pada penelitian ini, tetapi tidak langsung memberikan komentar ke public. STDI menahan dulu tanggapan dari Mahasiswa, Kopertais karena proses mengaktifkan kembali sedang berjalan statusnya. Hal ini dilakukan oleh STDI agar informasi mengenai pernyataan pokok masalah sesuai dengan kebenaran. Saat proses pengaktifan status dari non aktif menjadi aktif barulah PR melakukan diskusi dengan mahasiswa dan media untuk melakukan konfrensi pers yang ditujukan untuk menjawab semua pertanyaan media, mahasiswa dan alumni selama proses status aktif berjalan.

\section{Perencanaan (Planning and Programming)}

Setelah informasi tentang akar masalahnya dikumpulkan, maka PR akan mendapatkan gambaran yang jelas mengenai permasalahan yang sedang terjadi. PR perlu berusaha mengatasi permasalahan dengan merencanakan berbagai strategi PR untuk memastikan hubungan antara mahasiswa dan kampus membaik, strategi bersifat jangka pendek guna meredam keresahan mahasiswa. Dalam usaha perencanaan ini harus dapat ditentukan tujauan yang ingin disampaikan, karena tanpa tujuan yang nyata, maka tujuan perencanaan tidak akan tercapai. 
PR juga perlu memikirkan beberapa alternatif yang dapat memberikan dampak secara maksimal. Dalam usaha untuk menyebarkan informasi perlu juga ditentukan tekni penyebaran seperti media manakah yang sesuai untuk digunakan (Ruslan, 1998).

Dalam penelitian ini, peneliti tidak menemukan data yang dapat memperlihatkan PR memiliki perencanaan dalam strategi PR untuk mengatasi krisis, terkesan PR berjalan sendiri, reaktif dalam penyelesaiannya begitu disampaikan dalam wawancara dengan informan 2 senada yang disampaikan informan 1 kalau tidak tim khusus untuk mengelola krisis di unit STDI.

Menurut pandangan praktisi kehumasan, seharusnya humas harus melakkan perencanaan dengan strategi humas, perencanaan tersebut dapat melihat dari factor komunikasi yaitu crisis preparation. Ada 4 persiapan krisis : mitigasi, persiapan, respond dan evaluasi. Mitigasi merupakan langkah-langkah jangka panjang untuk mengantisipasi krisis.

\section{Mengambil Tindakan dan Berkomunikasi Melalui Program Strategi Integrated Marketing Communication (Action and Communicating)}

Tindakan dan komunikasi yang dilakukan oleh PR merupakan tindakan dan komunikasi STDI untuk menangani krisis. Diakuinya tidak ada tim khusus untuk memperbaiki krisis, Bekerjasama dengan Kopertais dan Kepala Bagian Sistem Penjamin Mutu Internal SPMISTDI yang juga sebagai Informan 1 melengkapi kembali laporan operasional dan mengawalnya hingga status aktif kembali di website forlap.dikti.go.id berdasarkan yang telah dilakukan 6 sebelum pemberitaan dimedia muncul. Hal ini dilakukan dengan tujuan untuk memeriksa kembali laporan secara lengkap guna mendapatkan kembali status aktif pada situs tersebut.

Selain itu PR melakukan hubungan dengan mahasiswa dan media (media relation) dengan menemui mahasiswa yang meminta kejelasan terhadap status tersebut, ditemuinya mahasiswa sebagai langkah meredam keresahan atas pemberitaan negative di media on line. Tindakan lain dilakukan dengan memonitoring pemberitaan oleh media tentang STDI. Setelah kegiatan monitoring dilakukan, PR mendapatkan hasil yaitu berita positif atau berita negative. Pemberitaan negative hanya ada di media online saat itu beritanya di Detik, Warta dan Tribun yang semuanya adalah pemberitaan negative yang bersumber dari website forlap.dikti.go.id dimana setiap orang bisa saja mengakses dengan mudah ke situs tersebut. Media yang memberitakan positf tetap dipegang oleh STDI. Media yang mengeluarkan berita negative dimasukan dalam aktifitas media relations. Meskipun PR tidak melakukan konfirmasi kepada media on line tersebut terkait citra pihak STDI juga tidak mengadakan peninjauan langsung kepada media tersebut hal ini dilakukan karena hasil keputusan rapat kordinasi PR dengan Pengurus Yayasan untuk bergerak secara tenang meredam krisis dengan cara memperbaiki laporan ke Kopertais. 
Selanjutnya STDI juga melakukan tindakan diskusi dengan mahasiswa melalui pertemuan intensive menceritakan kejadian yang sebenarnya berdasarkan fakta-fakta yang terjadi, dalam bentuk laporan yang sedang diproses di Kopertais, melakukan sosialisasi ke calon mahasiswa melalui kunjungan ke sekolah - sekolah SMA/SMK untuk membangun brand awareness, mengikut sertakan mahasiswa dalam lomba- lomba tingkat regional maupun Nasional.

\section{Integrated Marketing Communication Sebagai Strategi Keluar Dari Krisis.}

Kaitannya dengan penanganan krisis, Public Relation memiliki tanggung jawab besar, mengingat dampak negative dan kerugian besar, bahkan citra organisasi atau perusahaan terancam dengan adanya krisis. Adanya pemberitaan negative di media online berdampak pada menurunnya jumlah mahasiswa yang mendaftar sekitar $2 \%$.

Menurut Terence A. Shimp (2014) IMC merupakan suatu proses komunikasi yang memerlukan perencanaan, penciptaan, integrasi dan implementasi dari berbagai bentuk marcom ( iklan, promosi penjualan, publisitas perilisan, acara-acara dsb) yang disampaikan dari waktu ke waktu kepada pelanggan target merek dan calon pelanggan. Tujuan dari IMC pada akhirnya adalah untuk mempengaruhi secara tidak langsung atau secara langsung perilaku dari audiens yang menjadi target marcom. IMC mempertimbangkan semua titik sentuhan, ataupun sumber kontak, yang dimiliki pelanggan/ calon pelanggan dengan merek sebagai saluran penyampaian pesan dan menggunakan semua metode komunikasi yang relevan bagi pelanggan/ calon pelanggan. IMC mensyaratkan bahwa semua media komunikasi merek menyampaikan pesan yang konsisten. Proses IMC selanjutnya mengharuskan bahwa pelanggan calon pelanggan adalah titik awal menentukan jenis pesan dan media terbaik yang mampu menginformasikan, membujuk, dan mendorong tindakan yang diharapkan.

Untuk mengerti IMC, harus memahami pengertian dasar dari pemasaran, karena fungsifungsi IMC sendiri berada dibawah payung pemasaran. Seperti halnya pemasaran, IMC sendiri merupakan konsep sekaligus proses. Dalam konsepnya, IMC menciptakan customer dan brand equity; sedangkan dalam prosesnya memanage hubungan jangka panjang dengan customer dalam hal ini mahasiswa.

\section{Konsep IMC dan Penerapannya di STDI}

Hasil penelitian Bagian Promosi dan Public Relation belum memadukan fungsi-fungsi pemasaran seperti advertising, personal selling, sales promotion, public relation, seperti kkita ketahui Komunikasi pemasaran terpadu adalah konsep pemasaran dengan menerapkan 8 (delapan) strategi pemasaran secara bersama, yaitu :

\section{Pemasaran Langsung (Direct Marketing)}

STDI sebagai Top Of Mind bidang Design sedangankan Interstudi bidang Sekretaris diakui oleh informan saat ini organisasi berhubungan langsung dengan mahasiswa tanpa melalui retailer atau agent, maka digunakanlah direct-response marketing, seperti: 
melakukan kunjungan ke sekolah sekolah SMA dan SMK, Mengundang para siswa untuk merasakan langsung jurusan yang ada di Interstudi melaui program marketing experience, Mengikuti pameranEducation and Training Expo diadakan di JCC tiap tahunnya, yang dirancang dengan baik oleh bagian Promosi dan Public Relation.

Tambahnya lagi bagian Promosi tidak memberikan janji, biarkan calon mahasiswa merasakan langsung dan berpendapat sesuai dengan apa yang dirasakan. Harapannya mempertemukan harapan calon mahasiswa dengan apa yang diinginkan.

\section{Promosi Penjualan (Sales Promotion)}

Sales promotion merupakan istilah singkat dari penawaran nilai tambah yang dirancang untuk menggerakkan dan mempercepat respons dari customer. Hasil penelitian mendapati tidak ada program promosi yang dilakukan STDI sebagai contoh tidak ada program diskon bagi calon mahasiswa yang melakukan pendaftaran dibulan tertentu, program promosi diperuntukan kepada siswa berprestasi sebagai bea siswa.

Pada konsepnya promosi gunakan untuk memotivasi calon mahasiswa agar melakukan aksinya dengan membeli produk yang dipicu dengan adanya penawaran produk dalam jangka waktu yang terbatas.

Dalam penelitian ditemui belum ada program pemasaran yang tersistem dengan baik untuk program - program promosi yang di lakukan baik itu dalam pameran, kunjungan ke sekolah, iklan dimedia masa baik yang dilakukan oleh bagian promosi, staf lainnya, ataupun mahasiswa yang membantu mengenalkan STDI kepada masyarakat.

\section{Hubungan Masyarakat (Public Relations)}

Hasil penelitian mendapati adanya aktivitas dengan calon mahasiswa dengan mengundang calon mahasiswa ke kampus untuk merasakan bagaimana menjadi mahasiswa sebagai product experience, aktivitas lainnya mengadakan Events seminar untuk guru, siswa SMA/SMK memperkenalkan pentingnya produk yang dipasarkan, selain itu juga STDI berperan sebagai sponsor dalam pelaksanaan wisuda SMA/SMK pada tiap tahunnya, mengadakan festival seni dengan lomba band antar SMA juga dilakukan meskipun tidak berdampak besar karena jumlah peserta yang datang tidak sesuai dengan harapan, meskipun untuk melakukan ini memerlukan biaya yang cukup besar dengan jumlah tim promosi yang hanya 5 orang semuanya berjalan sesuai rencana.

\section{Penjualan Personal (Personal Selling)}

Personal Selling adalah komunikasi dua arah dimana seorang penjual menjelaskan fitur dari suatu brand untuk kepentingan pembeli. Dalam Personal Selling, dilibatkan komunikasi yang sifatnya tatap muka dan kegiatannya pada sekarang ini terfokus pada pemecahan masalah dan penciptaan nilai bagi customer (lebih dikenal sebagai partnership) Dimensi dari partnership ini adalah, seorang sales person harus memahami customer-nya dengan baik. 
Dalam wawancara ditemui aktivitas Personal seling tidak dilakukan secara sistematis artinya pengenalan dan penjualan produk tertumpu pada bagian promosi dan public relation terpusat, unit STDI tidak mendapatkan porsi untuk melakukan proses promosi secara baik, ditemui juga tidak diberlakukan sistem buyer get buyer dimana mahasiswa yang sudah merasakan kuliah tidak tersistem bagaimana jika mahasiswa membawa mahasiswa baru, Personal selling sendiri merupakan bagian dari direct marketing, namun perbedaan dasarnya adalah dalam personal selling, perusahaan yang dijembatani sales person berinteraksi secara tatap muka dengan customer. Penjualan personal yang dilakukan oleh bagian promosi dengan mengadakan pameran pendidikan dan presentasi dikelas-kelas 3 SMA/SMK

\section{Periklanan (Advertising)}

Pada saluran ini yang banyak menggunakan dana promosi, dengan beriklan di Majalah Go Girl (dengan pembaca dari kalangan muda wanita), Koran Kompas (dengan pembaca dari kalangan orang tua) alasannya sebagai pengambil keputusan akan disekolahkan dimana anak anaknya setelah lulus dimana tayangan iklannya diterbitkan 1 bulan sebelum penutupan pendaftaran atau persisnya setelah ujian masuk perguruan tinggi negri dilakukan.

Selain media diatas bagian promosi juga mengiklankan di Nett TV sebagai TV dengan jumlah pemirsa dari kalangan muda ini dianggap cocok untuk mengakomodir program promosi, design visual iklan biasanya dibuat oleh mahasiswa STDI sendiri. Tujuan advertising dipakai ketika suatu perusahaan ingin mengubah customer dari unaware, menjadi aware terhadap suatu brand aktivitas ini dinilai cukup efektif.

Aktivitas lainnya dengan mencetak brosur atau selebaran yang diberikan pada saat calon mahasiswa berkunjung ke kampus, saat pameran, atau saat tim promosi berkunjung ke sekolah.

\section{Publikasi (Publicity)}

Berbeda dengan pesaingnya seperti London School Public Relation yang kerap kali memasang papan iklan berisi himbauan seperti jauhi narkoba di persimpangan jalan jalan tingkat Kecamatan, atau mencetak stiker yang diletakan di belakang mobil pihan STDI belum melakukan ini dari hasil penelitian diakui pihak promosi belum melakukan program - program publikasi secara massif.

Walaupun PR menawarkan kredibilitas yang lebih besar dalam membangun publicity, namun advertsing dapat menawarkan awareness dan kontrol yang lebih besar. Lalu untuk beberapa alasan, maka sejumlah pesaing menyampaikan pesan PR mereka lewat advertising. 
Yang paling dirasakan untuk Publikasi adalah jika mahasiswa STDI memenangkan lomba fashion hasil karya mahasiswa STDI sering tampil di Indonesia Fashion Week atau Asosiasi Perancang Mode Indonesia membawa nama kampus, bahkan kita pernah menjadi juara ini bagian dari karya yang dihasilkan mahasiswa untuk membangun image kampus.

\section{Events/Sponsorship}

Event marketing adalah situasi yang signifikan atau peristiwa promosi yang mempunyai fokus utama untuk menangkap perhatian dan melibatkan customer dalam event tersebut. Yang telah dilakukan oleh pihak STDI dengan mensponsori kegiatan - kegiatan yang diadakan SMA/SMK seperti acara wisuda, pameran pendidikan, selain itu program sponsorhip diberikan bagi Unit Kegiatan Mahasiswa - UKM (meskipun sudah 3 tahun ini UKM tidak bergairah untuk menyelenggarkaan kegiatan) dengan melakukan kegiatan lomba band, lomba fashion, lomba animasi dimana siswa SMA/SMK sebagai pesertanya ini di nilai dapat meningkatkan brand awareness dan untuk menyediakan platform yang baik bagi brand publicity.

Sponsorship adalah dukungan finansial kepada suatu organisasi, orang, atau aktivitas yang dipertukarkan dengan publisitas merek dan suatu hubungan. Sponsorship dapat membedakan sekaligus meningkatkan nilai suatu merek. Beberapa pedoman yang digunakan oleh perusahaan-perusahaan dalam memilih sponsorship: target khalayak, penguatan citra merek, dapat diperpanjang, keterlibatan merek, biaya yang efektif dan sponsor lainnya.

\section{Interactive Marketing}

Dalam penelitian ini ditemua bahwa STDI belum memaksimalkan saluran ini diketahui belum adanya feet back form dimana mahasiswa dapat menyampaikan kritik dan saran terhadap performance dosen melakukan proses kegiatan belajar mengajar, social media sebagai media interaksi yang paling murahpun belum juga dimaksimalkan fungsinya ini baru akan dimulai meskipun sudah ada beberapa video hasil karya mahasiswa yang kita up load di youtube ini belum maksimal berbanding besarnya manfaat dari sosmed untuk proses interaksi mahasiswa dengan kampus.

\section{SIMPULAN}

Setelah melakukan analisis dan interprestasi data dari hasil wawancara dan berdasarkan data sekunder yang peneliti dapatkan dalam penelitian, beberapa kesimpulan sesuai dengan permasalahan dan tujuan penelitian, kesimpulan - kesimpulan yang diperoleh dalam penelitian ini adalah sebagai berikut : 
Sekolah Tinggi Desain Interstudi - STDI memiliki pemahaman mengenai krisis adalah mengenai pemberitaan negative dari media yang menjurus ke arah negative yang menyebabkan STDI menjadi pembicaraan di masyarakat, mahasiswa, orang tua dan calon mahasiswa, pemahaman ini sesuai dengan pemahaman krisis yang dinyatakan oleh Regester \& Larkin. Dimana krisis yang meresahkan mahasiswa sehingga terjadi demonstrasi meminta penjelasan dan penyelesaian terhadap permasalahan tersebut pemahaman tersebut sesuai dengan definisi krisis juga dikemukakan oleh Robert P.Powell.

Dalam mengelola keluar dari krisis STDI melakukannya secara naluri tanpa perencanaan yang matang bahkan terkesan tergesa - gesa, meskipun secara garis besar telah melaksanakan konsep-konsep strategi humas dalam mengelola krisis menurut Mccelreath yaitu : pendalaman fakta, perencanaan, mengambil tindakan dan berkomunikasi. Langkah langkah dalam mengelola krisis yang dilakukan oleh Public Relation STDI sepenuhnya tidak menjalankan konsep pengelolaa konsep krisis menurut Angela Muray dan Silih Agung Wasesa. Hal ini dikarenakan tidak mengetahuai mengenai teori pengelolaan krisis. Public Relation STDI menyadari pentingnya keluar dari krisis karena berkenaan dengan reaksi negative mahasiswa yang muncul, akibat keterbukaan informasi siapa saja dapat mengakses informasi yang diberitakan di media on line detik, warta dan tribun ini berdampak pada penurunan mahasiswa, citra yang buruk ini sesuai dengan teori Kathleen Fearn - Banks mengenai implikasi negative dari krisis.

Implementasi pemasaran melalui Integrated Marketing Communication masih dalam tataran konsep belum menjadi sebuah kebijakan yang tertuang dalam program kerja yang terukur secara pencapaiannya, rencana pemasaran belum secara komperhensif sehingga sulit melakukan evaluasi bertolak belakang dengan teori Belch, George E \& Belch, Michael A sebuah konsep dari perencanaan komunikasi pemasaran yang memperkenalkan nilai tambah dari rencana komprehensif yang mengevaluasi peran strategis dari berbagai disiplin komunikasi. Strategi, biaya dan personil pemasaran yang terbatas masih menjadi kendala pada bagian Promosi dan Public Relation sehingga kurangnya Koordinasi antara marketing, media dan promotional tools berdampak pada komunikasi produk jasa kurang efektif dan tidak merepresentasikan image dari produk jasa kepada target pasar. Strategi komunikasi pemasaran terpadu mampu menjadi pendekatan yang berbeda bagi organisasi yang terkena krisis, memperbaiki citra positif dan meningkatkan kepercayaan masyarakat. 


\section{DAFTAR PUSTAKA}

Ambadar, J., Abidin, M., \& Isa, Y.,(2001). Membangun Citra Perusahaan. Jakarta: Karisma.

Argenti, P. A. (2010). Komunikasi korporat. Jakarta: Salemba Humanika.

Braden, V., Cooper, I. I., Klingele, M., Powell, J. P., \& Robbins, M. G. (2005). Crisis-- $A$ Leadership Opportunity (No. CADRE/PC-2005-003). JOHN F KENNEDY SCHOOL OF GOVERNMENT CAMBRIDGE MA.

Cutlip, Scott M, Center, Allen. H, \& Broom, Glen. M (2006). Effective Public Relation, 6 Edition, New Jersey : Pearson Prentice Hall.

Hardiman, I. (2007). Karier Public Relations The Most Wanted Job. Jakarta: Gagas.

Henslowe, P. (2003). Public relations: A practical guide to the basics. Kogan Page Publishers.

Kapferer, J. N. (1994). Strategic brand management: New approaches to creating and evaluating brand equity. Simon and Schuster.

Kusumastuti, F. (2002). Dasar-dasar humas. Jakarta: Ghalia Indonesia.

Normann, R. (1991). Service management: strategy and leadership in service business. Wiley.

Ruslan, R. (2008). Manajemen public relations dan media komunikasi: konsepsi dan aplikasi. Jakarta: Raja Grafindo Persada.

Sutojo, S. (2011). Handbook of Public Relation. Jakarta: Ardianto.

Toriq, A. (2015). Ini Daftar 243 Kampus yang Dinonaktifkan Kemenristek Dikti. https://news.detik.com/berita/d-3033481/ini-daftar-243-kampus-yangdinonaktifkan-kemenristek-dikti 